Александра Смирнов-Бркић

Универзитет у Новом Саду

Филозофски факултет

Одсек за историју

aleksandrasmirnov@gmail.com
Оригинални научни рад

примљено: 1. јун 2012

прихваћено: 1. октобар 2012

\title{
ИЗГНАНСТВО АРИЈА У „ИЛИРИК“ ПРЕМА ИСТОРИЈСКИМ ИЗВОРИМА*
}

\begin{abstract}
Сажетак: У раду се анализира питање места изгнанства александријског презвитера Арија, после осуде његовог учења на Првом васељенском сабору у Никеји 325. год. У научној литератури опште је прихваћен податак да је Арије са још неколицином истомишљеника прогнан у „Илирик“, са варијацијама на питање прецизније убикације (Сирмијум, Сердика, Наисус као најчешћа решења). Рад ће критички изложити податке античких извора о Аријевом изгнанству, затим сагледати питање Аријевог присуства у Илирику у светлу археолошких извора и на крају изнети закључак о могућности поузданог утврђивања места изгнанства оснивача аријанске јереси с обзиром на стање историјских извора.
\end{abstract}

Кључне речи: Арије, аријанство, Илирик, Сирмијум, Валенс, Урсације, Панонија

Једна од најдуготрајнијих христолошких расправа позната као аријански спор започета је када је александријски презвитер Арије међу својом паством проповедао божанску различитост Бога Сина и Бога Оца, тачније када је вест о овим проповедима дошла до свештеничког круга око александријског епископа Александра. Иако гледиште о Христовој људској природи и његовој божанској подређености Оцу није било ново и већ је нашло своје присталице у школи Лукијана из Антиохије, чији је и Арије био ученик, ${ }^{1}$ тек је у Александрији 324. год. покренут званични процес осуде са далекосежним последицама које ће потресати цео хришћански свет током 4. века. Штавише, тежина овог црквеног спора имала је за последицу увлачење римске државе преко личности римског цара у унутрашња

\footnotetext{
* Текст је настао као фазни резултат рада на пројекту Средњовековна насеља на тлу Војводине. Историјски процеси и догађаји, бр. Решења 114-451-2216/2011, који финансира Покрајински секретаријат за науку Владе Аутономне покрајине Војводине.

${ }^{1}$ О пореклу Аријевог учења вид. Rowan Williams, Arius. Heresy and Tradition, Revised Edition, Cambridge 2002, 29-32.
} 
питања Цркве. ${ }^{2}$ И поред тога што Свето писмо није имало јасан и директан одговор на питање консупстанционалности, александријска црквена хијерархија изнела је Аријево гледиште на јавну осуду и избацила га из црквене заједнице. Сукоб је настао јер Црква није била јединствена у то време нити је имала конституисану хијерархију, те су се црквена седишта сматрала равноправним и легитимним да доносе одлуке о питањима догме. Арије се жалио водећим црквеним лицима ван Александрије, те је сазван сабор у Антиохији 324. год. који је ипак подржао александријског епископа, али је на том сабору постало јасно да има и Аријевих истомишљеника, од којих су најеминентиније личности били епископ палестинске Цезареје Еусебије и његов имењак, епископ Никомедије. Питање је на крају одложено за предстојећи Никејски сабор који је сазвао римски цар Константин I Велики (306-337) због решавања крупних црквених питања, којима је тада било додато и Аријево учење. Пошто је аријанство осуђено на Никејском екуменском сабору 325. год, Арије је прогнан у „Илирик“, заједно са епископом Секундом из Птолемајиде, Теоном из Мармарике и још неким александријским свештеницима. ${ }^{3}$ Одлуку о прогону Арија и његових следбеника на крају Сабора донео је сам цар Константин, јер је једино тако она могла имати правну снагу. ${ }^{4}$ Овај рад има за циљ да да̄ критичку анализу овог општег места у историографији и Аријев прогон у „Илирик“ представи према стању данас доступних историјских извора.

Према основном принципу савремене историографије очекивало би се стога да општеприхваћени податак попут поменутог о Аријевом прогону има широку аргументацију засновану на писаним сведочанствима примарних извора. Од сачуваних докумената о осуди Арија и његовом прогону хронолошки су најстарија акта Никејског сабора са анатемама осуђених, ${ }^{5}$ затим писмо Никејског сабора египатским и либијским црквама (325), ${ }^{6}$ у коме се шаље позив за осуду Арија и његовог учења. Следи Константиново писмо свим црквама против Арија и Порфиријанаца, у коме се прети смртном казном сваком ко скрива Аријеве списе $(325)^{7}$, потом царево писмо цркви Александрије о одлукама Сабора (325), ${ }^{8}$ царево

\footnotetext{
2 Литература о аријанству је данас заиста богата, с тим да је немачка историографија дала највећи хеуристички допринос, вид. Eduard Schwartz, Die Dokumente des arianischen Streites bis 325, Nachrichten von der königlichen Gesellschaft der Wissenschaften zu Göttingen (даље NGWG), 1905, 257-99 = Gesammelte Schriften, Bd. 3, 117-68; Von Nicaea bis zu Konstantins Tod. Eine grundsätzlich andere Chronologie, die allerdings auch von der Spätdatierung des Todes des Arius Mitte der dreißiger Jahre ausgeht, NGWG, 1911, 367-426 = Gesammelte Schriften, Bd. 3, 188-264; Hans-Georg Opitz, Urkunden zur Geschichte des arianischen Streites, 318-328 (даље Urk.), у: Athanasius’ Werke, Bd. 3, Berlin 1934; Die Zeitfolge des arianischen Streites von den Anfängen bis zum Jahr 328, Zeitschrift für die neutestamentliche Wissenschaft und die Kunde der älteren Kirche (даље ZNW) 33, 1934, 131-159; Hanns C. Brennecke, Uta Heil, Annette von Stockhausen, Angelika Wintjes, Athanasius Werke, Bd. 1-3, Bd. 3.1: Dokumente zur Geschichte des arianischen Streites, Berlin - New York 2007.

${ }^{3} \mathrm{O}$ току процеса против Арија на Никејском сабору, вид. R. Williams, нав. дело, 67.

${ }^{4}$ Hanns Christof Brennecke, Nicäa I. Ökumenische Synode von 325, Teologische Realenzyklopädie, Bd. 24, 1994, 429-441.

${ }^{5}$ Ath. Decr. 36-37; Thdt. HE 1.12; Socr. HE 1.8; Gel. Cyz. HE 2.34.

${ }^{6}$ H.-G. Opitz, Urk. 23, 47-51; Socr. HE 1.9.

${ }^{7}$ Eus. VC 3.17-20; Socr. $H E$ 1.9; Thdt. $H E$ 1.10; Gel. Cyz. $H E$ 2.37.10.

${ }^{8}$ Ath. Decr. 38; Socr. HE 1.9; Gel. Cyz. HE 2.37.
} 
писмо осуде Арију и аријанцима (325), ${ }^{9}$ нејасна изајава праве вере Арија и Еузоија послата Константину из изгнанства (крајем 327), ${ }^{10}$ Константинов позив Арију да дође у Никомедију и оправда се како би што пре могао да се врати у своје седиште (327?), ${ }^{11}$ Константиново писмо епископу Александру Александријском у коме га обавештава о Аријевом доласку на двор и његовој потврди праве вере (пре 328), ${ }^{12}$ део Константиновог едикта против Арија и његових следбеника после поновне осуде $(c .333)^{13}$ и Константиново писмо Арију док је овај боравио у близини Александрије, у коју му је забрањен приступ (333) ${ }^{14}$. Ниједан од поменутих докумената, који су иначе сачувани само у копијама код позноантичких црквених писаца, не помињу где је Арије послат. ${ }^{15}$

Пошто нема других докумената о Аријевом прогону, преостају бројна историографска дела савременика и учесника аријанског спора, ${ }^{16}$ од којих су најисцрпнији и директно везани за проблем аријанства поједини списи и писма св. Атанасија, епископа Александријског (c.296-373) (Historia Arianorum, Orationes contra Arianos, Apologia contra Arianos, De Synodis, De decretis Nicaene, итд.) и св. Иларија, епископа Пиктавија (данас Поатје) (с.315-367/8) (De synodis, Contra Arianos, Contra Valens et Ursacius, De Trinitate). ${ }^{17}$ Међутим, кључна, али и једина, информација о Илирику као месту Аријевог прогонства после Никејског сабора налази се само код аријанског историчара Филосторгија (c.368-c.439), и то у једној епитоми волуминозног дела византијског црквеног историчара Никите Хонијата

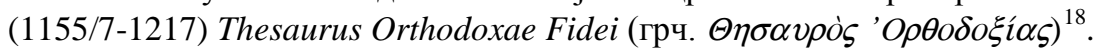

Кападокијац Филосторгије био је следбеник оснивача тзв. аномејског аријанства, теолога и кизичког епископа Еуномија (умро c.399). ${ }^{19}$ Његово главно дело Црквена историја (Historia Ecclesiastica), сачувана само у фрагментима и

\footnotetext{
${ }^{9}$ Conc. 2.269.

${ }^{10}$ Socr. $H E 1.26$.

${ }^{11}$ Socr. HE 1.25. За хронологију упор. Timothy Barnes, The Exile and Recalls of Arius, Journal of Theological Studies, NS, 60, April 2009, 109-129; Richard P. C. Hanson, The Search for the Christian Doctrine of God. The Arian Controversy 318-381, Edinburgh 1988, 176.

${ }^{12}$ Gel. Cyz. HE 3.15.1.

${ }^{13}$ Прилог у Ath. Decr; Gel. Cyz. HE 3.19.1; на сиријском вид. Fredrich Schulthess, Die syrischen Kanones der Synoden von Nicaea bis Chalcedon, Abhandlungen der Königlichen Gesellschaft der Wissenschaften zu Göttingen, Philologisch-Historische Klasse N.F. 10, no. 2, Berlin 1908, 1-2.

${ }^{14}$ Socr. HE 1.25.726; Soz. HE 2.27.6-10.

${ }^{15}$ Ath. Apol. adv. Ar. 59; Socr. HE 1.27; Soz. HE 2.22; Gel. Cyz. HE 3.14, 3.15; E. Jonkers (ed.), Acta et symbola Conciliorum quae saeculo quarto habita sunt, Leiden 1954.

${ }^{16}$ Поред поменутих аутора о аријанском спору говоре и сачувани фрагменти или епитоме аријанског историчара Филосторгија, затим Црквена историја и Живот Константинов Еусебија Цезарејског, као и историје црквених писаца са краја 4. и почетка 5. века Сократа Схоластика, Созомена, Теодорета, Руфина, Геласија; за изворе о аријанству вид. бел. 2.

17 Вид. Н.-G. Opitz, Athanasius' Werke, Bd. 1-3, Berlin 1934; Mauritii Geerard (ed.), Clavis Patrum Graecorum, Turnout 1974; Eligius Dekkers (ed.), Clavis patrum latinorum, Steenburgen 1995.

18 Збирка Никитиних списа налази се у Jacques-Paul Migne, Patrologiae cursus completus, s. Graeca (даље $P G)$, 1844-1855, vol. 139, 287-1444.

${ }^{19}$ О Еуномију и аномејству вид. F. L. Cross, Е. A. Livingstone, The Oxford Dictionary of the Christian Church, 3rd Ed, Oxford 1997, 1281.
} 
епитомама, писана је стога са аријанског становишта и вероватно са већим интересовањем за кретање Аријевих присталица. Ипак, овај извор треба користити с великим опрезом, јер није сачуван оригинални текст, већ у изводима код црквених личности које су негативно гледале на његово проаријанство, те су могли да селективно и тенденциозно преузимају податке. Прва издања Филосторгијеве историје навођена су према епитомама код патријарха Фотија (9. век) и у деветој

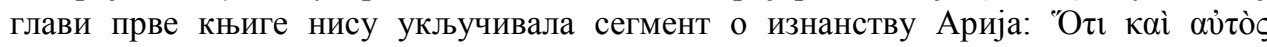

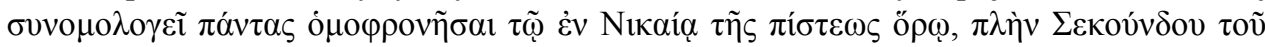

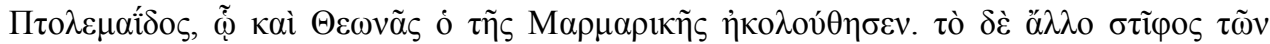

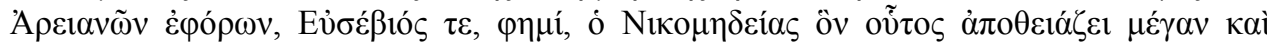

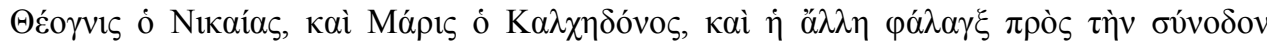

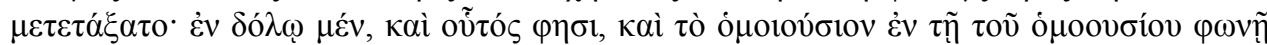



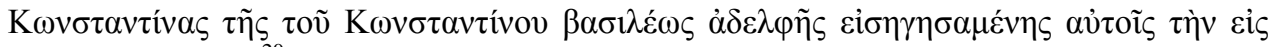



Белгијски класични филолог Жозеф Биде (Joseph Bidez), који се бавио црквеном историјом позне антике и посебно 4. века, у свом издању Филосторгијеве историје сакупио је све до тада познате фрагменте и допунио Фотијево издање. ${ }^{21}$ Према епитоми коју је нашао код Никите Хонијата, Биде поменути сегмент (1.9)

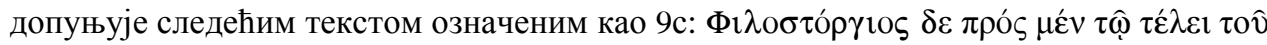

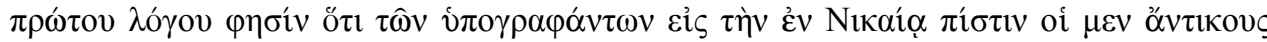

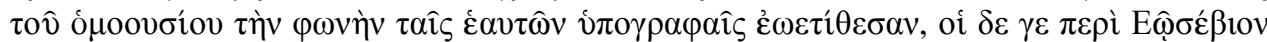

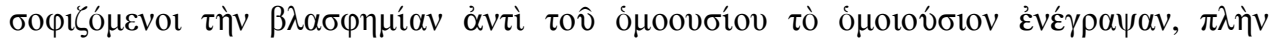

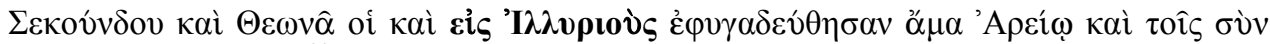

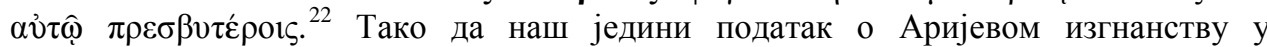
„Илирик“, као што видимо из наведеног пасуса, своди се дословце на прогон „међу Илире“, тј. у земљу Илира.

У антици под грчким називом 'І $\lambda \lambda v \rho i ́ \alpha$ и латинским Illyricum подразумевала се област западног Балкана где су живела племена која су Грци и Римљани објединили под именом Илири. ${ }^{23}$ Потом је Илирик као провинција предат на пет година Цезару законом Lex Vatinia 59. год. пре н. е, а после устанка двојице Батона (6-9. год.) провинција Илирик је претворена у две нове провинције, Панонију и Далмацију. Међутим, име Илирик као земља где су живели Илири задржаће се у употреби код античких писаца до половине 4. века, слично као што је употребљаван назив Галија. У време којим се овај рад бави, Илирик је у оквиру административних реформи Константина Великог организован као префектура најпре са седиштем у Сирмијуму, која је обухватала дијацезу Македонију и дијацезу Панонију, што преведено на данашњу политичку географију оквирно обухвата територију бивше

\footnotetext{
${ }^{20}$ Према J.-P. Migne, $P G$ 65, 459-624.

${ }^{21}$ Philostorgius. Kirchengeschichte. Mit dem Leben des Lucian von Antiochien und den Fragmenten eines arianischen Historiographen (Joseph Bidez Hrsg.), Leipzig 1913, 11.

${ }^{22}$ Nicetas, Thesaur. 5.8 y: J.-P. Migne, $P G$ 139, 1369.

${ }^{23}$ Упор. Фанула Папазоглу, О појмовима „Епир“ $и$ „Илирија“ у познорепубликанско доба, Годишњак Центра за балканолошка испитивања 13, 1976, 197-211; J. Wilkes, The Illyrians, Oxford 19962.
} 
Југославије, затим Румуније, Бугарске и Грчке. ${ }^{24}$ Током 4. века административне границе Илирика су се мењале, а коначно се подела усталила тек после смрти Теодосија I, када је Илирик добио облик у ком се јавља у Notitia dignitatum обухватајући дијацезу Панонију, Македонију и Дакију са седиштем у Солуну под суверенитетом источног цара. Како наша информација о Аријевом прогону потиче из извода писца осам векова касније, када ни Илири ни илирска префектура нису постојали, ${ }^{25}$ покушај прецизинијег одређивања Филосторгијевог појимања места Аријевог прогона у оквиру те „земље Илира“ ставља бројне потешкоће. Ипак, известан траг даје нам сам Филосторгије када касније у његовом делу поново

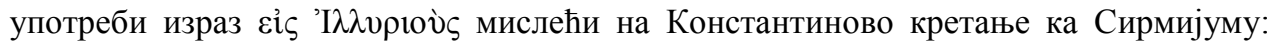

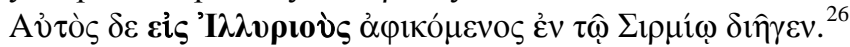

Већина истраживача који су се бавили проблематиком аријанског спора нису се директно бавили питањем места Аријевог изгнанства, те је Филосторгијев податак некритички преузиман, а истраживања су првенствено ишла у смеру утврђивања тачне хронологије, ${ }^{27}$ а не убикације егзила. Ханс Георг Опиц, ${ }^{28}$ који је критички издао дела св. Атанасија, сматрао је да је Арије тек три месеца ${ }^{29}$ након Никејског сабора, заједно са Еусебијем из Никомедије и Теогнидом из Никеје био послат у Галију, чиме у ствари следи раније мишљење Едварда Шварца. Велики сакупљач грађе за проучавање екуменских сабора и самог аријанског спора, немачки класичар Едвард Шварц сматрао је да Арије није одмах по завршетку Сабора изгнан у Илирик, већ да га је цар држао у притвору у Никомедији. ${ }^{30}$

Први који је исказао извесну сумњу у место Аријевог изгнанства, наговештавајући да ту ствар треба подробније испитати, јесте реномирани стручњак за религијска питања 4. века, професор единбуршког универзитета Тимоти Барнс. ${ }^{31}$ Иако Барнс не улази дубље у ову проблематику и генерално не оповргава да је у питању Илирик, он даје кратак историјат овог проблема, али се такође базира на утврђивању хронологије. ${ }^{32}$

\footnotetext{
${ }^{24}$ Šašel Kos, Marjeta (Ljubljana). "Illyricum." Brill's New Pauly. Antiquity volumes edited by: Hubert Cancik and Helmuth Schneider. Brill, 2012. Brill Online. THE GRADUATE INSTITUTE GENEVA. 21 February 2012 http://www.brillonline.nl/subscriber/entry?entry=bnp_e523320; упор. Nikola Vulić, Illyricum, RE, Bd. IX.1, 1087.

${ }^{25}$ John H. Rosser, Historical Dictionary of Byzantium, Boston 2001, 203.

${ }^{26}$ Philost. HE 4.3a (Bidez 59.25).

${ }^{27}$ Wilhelm Schneemelcher, Zur Chronologie des arianischen Streites, Theologische Zeitschrift (Basel), 79, 1954, 393-400.

${ }^{28}$ H.-G. Opitz, Die Zeitfolge, 140.

${ }^{29}$ Овде се Опиц водио Филосторгијевим податком, вид. Philost. HE 2.1.

${ }^{30}$ E. Schwartz, Von Nicaea, 367-426.

${ }^{31}$ T. Barnes, The Exile, 125.

32 Односно Барнс брани Шварцов став да писмо Константина I прочитано у Александрији пред префектом Патеријем треба датирати у 333. год, а не 320-те како су предложили најновији уредници некадашњег Опицовог монументалног издања опуса св. Атанасија, упор. Hanns C. Brennecke, Uta Heil, Annette von Stockhausen, Angelika Wintjes, Athanasius Werke, Bd. 1-3, Bd. 3.1: Dokumente zur Geschichte des arianischen Streites, Berlin - New York 2007, xix-xxxviii.
} 
Дакле, ако се место Аријевог прогона своди на терцијарни податак из Филосторгијеве историје, нови трагови се могу тражити у општој законској основи изгона јеретика у Позном римском царству, чиме би се утврдило да ли се на основу кодификоване правне процедуре или поређењем познатих случајева могу утврдити типична места.

У последњих педесет година дошло је до критичког преокрета у изучавању римског права. Ранија идеализована представа о функционалности и темељности римског правног система замењена је реалнијом сликом бројних недостатака римског права, а нарочито његовог казненог дела. Криминално право било је у односу на приватно права знатно слабије кодификовано, нарочито када су у питању верски преступи, и често се сводило на обичајно и практично право. ${ }^{33}$ Новија истраживања утврђују правну основу прогона верских преступника, посебно хришћана, истичући тиме да је проучавање религије у Римском царству неодвојиво од историје римског права на ком се базирао читав римски друштвени поредак. ${ }^{34}$ Религија и право били су повезани на два нивоа - спољашњем, формалном, који се рефлектовао у државним процесима усмереним ка религијским питањима, и унутрашњем, садржајном, кроз који је римско верско право у реципрочном односу према настајућем црквеном праву било изложено „христијанизацији“, кроз постепено прожимање Мојсијевим законом и хришћанским моралом и етиком. Да бисмо схватили како је од прогона хришћана од стране римске државе дошло до прогона јеретика морамо узети у обзир слојевитост римског права и домене државне јурисдикције. Улпијан (3. век) пише да ius publicum за разлику од ius privatum, које се односи на добробит појединца, обухвата ствари које се тичу светог, свештеника и магистрата, јер оне утичу на добробит државе и друштва. ${ }^{35}$ Још од времена Апија Клаудија (4. век пре н. е.) држава је на основу јавног права била надлежна за контролу култа. Државна интервенција подразумевала је одређивање правилног понашања у односу на култ богова римског народа од којих је зависио просперитет државе. Самим тим ненарушавање и одржавање уобичајеног култа постало је синоним за државну лојалност, ${ }^{36}$ а ремећење верског морала значило је компромитовање salus populi Romani. Када је под Константином Великим и правно и фактички хришћанство постало призната религија у Римском царству, која не угрожава добробит народа, сви државни механизми употребљени су тада против оних који угрожавају мир између осталог и у хришћанској цркви. Тако је правно било могуће да хришћанска црква постане једна од римских верских институција која ће и сама подржати све бруталне правне мере према својим непријатељима, које је раније римска држава користила према њој, што ће нарочито бити изражено

\footnotetext{
${ }^{33}$ Karl Leo Noethlichs, Revolution from the top? "Orthodoxy" and the persecution of heretics in imperial legislation from Constantine to Justinian y: Clifford Ando, Jörg Rüpke (eds.), Religion and Law in Classical and Christian Rome, Munchen 2006, 115.

${ }^{34}$ G. E. M. De Ste. Croix, Why Were the Early Christians Persecuted? Past\&Present 26, Nov. 1963, 6-38; Why Were the Early Christians Persecuted? - A Rejoinder, Past\&Present 27, Apr. 1964, 28-33.

${ }^{35}$ Ins. I fr. 1908 = Dig. 1.1.1.2.

${ }^{36}$ Упор. Cic. De natura deorum 3.94.
} 
у аријанском сукобу. ${ }^{37}$ Правно, као велики понтифик, цар је имао обавезу да учествује у решавању верских проблема зарад јавног мира и реда. Не треба заборавити чињеницу да конституисање екуменског сабора настаје на иницијативу и под покровитељством Константина Великог. Тако је већ у време донатистичког спора Константин слао у егзил проблематичне епикопе, а потом их и без сазивања сабора рехабилитовао. Немамо разлога да у случају Арија и његових следебеника мислимо да се одступило од исте процедуре.

Наш главни извор Константиновог законодавства, Теодосијев кодекс, који је на жалост скраћена и селективна компилација закона сакупљена век касније, посебно оскудева у верским прописима његовог доба. Правна средства која су римски цареви користили за промулгацију закона варирају у форми, те су снагу закона имали едикти (edictum/rescriptum/subscriptio), писма (epistula), декрети (decretum), мандати (mandatum). ${ }^{38}$ Како нема сачуваних законских аката који сведоче о процедури прогона, може се урадити типолошка студија познатих случајева како бисмо утврдили праксу. Студија Марка Густафсона говори о осуди на рад у рудницима или каменоломима (лат. metalla) у Позном римском царству и износи важне аргументе у контексту праксе прогона. ${ }^{39}$ Наиме, Густафсон је упоредио како се старо римско казнено право прилагодило новој христијанизованој држави. Телесне казне и осуде на рад у рудницима и каменоломима постојале су још од републиканског времена, ${ }^{40}$ али оне се у позној антици преносе на хришћане у току државних прогона, и још значајније после престанка прогона на јеретике. ${ }^{41}$ Сама казна прогонства, према римском праву означавала је ограничену слободу кретања и деловања. ${ }^{42}$ Из списа св. Атанасија сазнајемо која су места била најчешћа за изгнанство у руднике. Најгори су били рудници у Фену (лат. Phaeno), ${ }^{43}$ затим Порфирној гори (лат. Mons Porphyrites, дан. Gebel Abu Dukhan) и Монс Клаудијанус (лат. Mons Claudianus) у источној египатској пустињи, које и Еусебије ${ }^{44}$ помиње као место прогона хришћана, а потврдила су и новија археолошка ископавања. ${ }^{45}$ Потом се помиње Проконес на острву Мармара на Пропонтиди, ${ }^{46}$ бројна места у Малој

\footnotetext{
${ }^{37}$ Црквени оци осудили су ове прогоне међу хришћанима као горе од царских, упор. Rufin. HE 11.3.10; Socr. HE 2.27.38; 7.3.15.

${ }^{38}$ P. R. Coleman-Norton, Roman State and the Christian Church. A Collection of Legal Documents to A.D. 535, vol. I-III, London 1966, 1.7.

${ }^{39}$ Mark Gustafson Condemnation to the Mines in the Later Roman Empire The Harvard Theological Review, Vol. 87, No. 4 (Oct. 1994), 421-433.

${ }^{40}$ Fergus Millar, Condemnation to Hard Labour in the Roman Empire, from the Julio-Claudians to Constantine, Papers of the British School at Rome 52, 1984, 125.

${ }^{41}$ Вид. Eus. HE 9.1.7. Упор. Timothy D . Barnes, Constantine and Eusebius, Cambridge 1981, 159, 225; Peter Garnsey, Religious Toleration in Classical Antiquity, in: W. J. Sheils (ed.), Persecution and Toleration, Studies in Church History 21, Oxford, 1984, 19.

42 Theodor Mommsen, Romisches Strafrecht, Leipzig 1899, 949-951.

${ }^{43}$ Ath. Hist. Ar. 60. 2.

${ }^{44}$ Eus. De martyribus Palaestinae 8.1.

${ }^{45}$ Steven E. Sidebotham, Ronald E. Zitterkopf, John A. Riley, Survey of the 'Abu Sha'ar-Nile Road, American Journal of Archaeology 95, 1991, 575-76, 620.

${ }^{46}$ Thdt. HE 4.22.2.
} 
Азији, Галија, Тракија, Илирик, али никаква процедурална доследност се не примећује. Једини закон сачуван о овој врсти казне потиче из каснијег времена, када су 428. год. Теодосије II и Валентинијан III издали едикт против свих јеретика (аријана, мацедонијана, аполинаријана, новатијана, сабатијана, валетнинијана, монтаниста, присцилијаниста, марцијаниста, месалијана, донатиса, фотинијана, павликијана, манихеја и других) и њихових помоћника, од којих би помоћници били осуђени на тешки рад in metalla. ${ }^{47}$

Сара Парвис, пак, тврди да је могуће утврдити шаблон по ком је Константин слао у изгнанство црквене преступнике Истока. ${ }^{48}$ Наводно, он се водио следећим принципима: водеће личности Истока које су имале политичког и друштвеног утицаја (попут Еусебија, Теогнида и Атанасија) слао је у Тријер, своју бившу престоницу, одакле би комуникација са њиховим седиштем била знатно успорена и где је имао пуни надзор над њиховим кретањем; а мање проблематичне личности, попут Еустатија, Арија и Еузоија, слате су у Илирик. Парвисино тврђење изведено на сувише малом узорку не дозвољава овако екстреман научни суд. Иако су поменути егзили потврђени у изворима, поменута Густафсонова студија ${ }^{49}$ и наводи у изворима, указују да је тих места било знатно више. И сам св. Атанасије пише да је био послат на више места, као и епископ Луцифер од Каљарија. Такође, папа Либерије био је 356. год. прогнан у Тракију, св. Иларије исте године на сабору у Бетери (лат. Baeterrae) осуђен је на прогонство у Малу Азију. ${ }^{50}$ Када говори о изгону епископа Паулина из Тријера, кога је цар Констанције на сабору у Арлу 353/4. год. протерао у Фригију, св. Иларије наводи податак који може бити од значаја за утврђивање процедуре прогона. Он каже да је цар променио место првобитног Паулиновог прогонства у место „ехtra christianum nomen”, ${ }^{1}$ jep није желео да га храни из царске житнице нити да му пружи прилику да добије вотивне дарове код пећине Монтана и Максимиле. Тако да је у случају Арија Илирик био област у којој није постојала снажна хришћанска организација, посебно ка северу Паноније.

Парвисова даље разрађује тезу да је Арије био прогнан у један од три важна балканска града, Сирмијум, Сердику или Наисус, јер они као илирски градови одговарају горе утврђеним принципима прогона. ${ }^{52}$ То потврђује случај првака консупстанцијалности, епископа Еустатија из Антиохије, који је прогнан такође у

\footnotetext{
${ }^{47}$ Cod. Theod. 1 6.5.40. Временом су казне постале оштрије, те је рад у рудницима постао блажа казна у односу на погубљења, Cod. Theod. 16.1.4; 16.5.9; 16.5.56; 16.5.34.1; 16.5.36.1; 16.5.51. Вид. Ramsay MacMullen, Judicial Savagery in the Roman Empire, Chiron 16, 1986, 43-62.

${ }^{48}$ Sara Parvis, Marcellus of Ancyra and the lost years of Arian controversy, London 2006, 97-98, 106-107, 132133.

${ }^{49}$ Вид. бел. 39.

${ }^{50}$ Он је оставио спис који нам говори о том прогонству, али без назнаке места, вид. Т. D. Barnes, Hilary, 129-140. Иларије наводи и да су епископи Паулин из Тријера, Еусебије из Верчелија, Луцифер из Каљарија, Дионисије из Милана сви били осуђени на прогонство, Hil. Pict. In Const. 2.1-20.

${ }^{51}$ Иcmo, 11.14-37: ipsum usque ad mortem demutasti exiliis et fatigasti, extra christianum quoque nomen relegasti, ne panem aut de horreo tuo sumeret aut de Montani Maximillaeque antro profanatum expectare.

${ }^{52}$ Sara Parvis, Marcellus, 135.
} 
Илирик, ${ }^{53}$ према Теодорету он је спроведен кроз Тракију у „илирски град“, ${ }^{54}$ који би

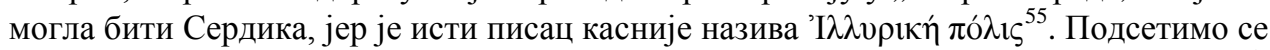

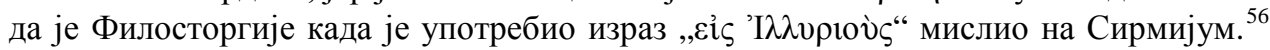
Поменута копија писма Константина Великог Арију, коју наводи Сократ Схоластик, ${ }^{57}$ у коме га подсећа да му је недавно „изручен“ позив да дође на његов двор у Никомедију да да̄ изјаву о вери и изненађен што овај то није учинио раније наређује му да сместа дође на двор о трошку јавног превоза, како би после разговора могао што пре да се врати у своју земљу. Према реконструисаном итинерару цара Константина, он је у Сирмијуму боравио 326. год. и током марта и априла 329. год, а у време када је Арију послао ово писмо 327/8. год. могуће је да се цар тамо срео са Аријем. ${ }^{58}$

Из наведеног можемо закључити да је одређивање места прогона верских осуђеника била ствар техничке и практичне природе. Самим тим немогуће је позивати се на неку доследну процедуралну одлуку код питања места изгнанства самог Арија. Једини смислени закључак односи се на тенденцију прогона на просторе на којима је хришћанство било слабије заступљено и далеко од места деловања осуђеника, а које је уједно било у близини неког административног центра чиме је обезбеђиван државни надзор.

Како и даље утврђени подаци не задовољавају, преостаје још један модус приступа проблему. Наиме, испитивањем писаних извора о двојици аријанских епископа са подручја Илирика, који су имали кључну улогу у аријанским расправама после Никеје. Многе ауторе је баш та појава аријанства у Панонији, непосредно после Аријевог прогона, навела да у епископима Валенсу из Мурсе и Урсацију из Сингидунума нађу логичну потврду Аријевог боравка у тим крајевима. Мађарски стручњак за историју и археологију Паноније, Андраш Мочи такође везује активност Валенса и Урсација за Аријево изгнанство у Илирик, и додаје да су они послали проникејског епископа Сирмијума, Домнија, потписника Никејског симбола, у егзил заменивши га аријанцем Еутеријем. ${ }^{59}$ Заиста, међу потписницима одлука Никејског сабора налази се име епископа Домнија из Паноније, који се не убраја у подржаваоце Арија. ${ }^{60}$ Филосторгије наводи имена двадесет и двојице епископа који су подржали Арија на Сабору. Очекивало би се да су на тој листи и Валенс и Урсације, међутим како је Вилијамс уочио на тој листи се налазе и имена двојице епископа који су тада већ били преминули, те је не можемо сматрати

\footnotetext{
${ }^{53}$ Socr. HE 1.24; Soz. HE 2.19; Thdt. HE 1.20; Philost. HE 2.7; Eus. VC 3.19.

${ }^{54}$ Thdt. HE 1.22.1.

${ }^{55}$ Thdt. HE 2.4.6.

${ }^{56}$ Philost. HE 4.3a (Bidez 59.25), упор. стр. 4 овог рада.

${ }^{57}$ HE 1.25 .

${ }^{58}$ Timothy Barnes, The New Empire of Diocletian and Constantine, London 1982, 77-79.

59 Ath. Fug. 5.2, вид. A. Mocsy, S. Frere, Pannonia and Upper Moesia. A History of the Middle Danube Provinces of the Roman Empire, London-Boston 1974, 330.

${ }^{60}$ Thdt. HE 1.6.
} 
поузданом. ${ }^{61}$ Созомен наводи да су седамнаесторица подржала Арија на почетку Сабора, али не именује Валенса и Урсација. ${ }^{62}$

Атанасије Александријски, који је на Никејском сабору био de facto вођа опозиције против Арија и најагресивнији и најистрајнији борац против аријанства у постникејском периоду, уједно је и најплоднији писац на ову тему. Те, иако нигде у својим списима не помиње место Аријевог изгнанства, он истиче Аријеву везу са Панонијом и каснијим „аријанским“ епископима Валенсом из Мурсе и Урсацијем из Сингидунума. ${ }^{63}$ Жак Зеје ${ }^{64}$ у до сада јединој научној монографији о раном хришћанству у доњедунавским провинцијама, не доводи у питање Аријево изгнанство у Панонију и потврду Филосторгијевог навода налази у писму св. Атанасија епископима Либије и Египта (356), које о Валенсу и Урсацију каже: Каі̀

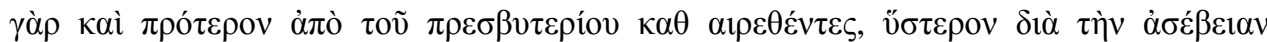

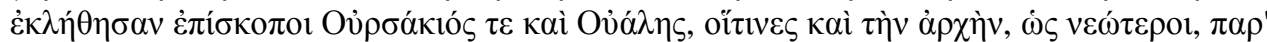

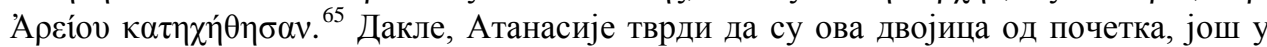
младости били подучавани од Арија, а како се они не наводе као учесници Никејског сабора већ тек од сабора у Тиру 335. год. где подржавају осуду св. Атанасија, тај период учења од Арија морао је бити у току његовог прогона. Исто тако, св. Иларије изражава сумњу и отворено оптужује Валенса и Урсација ${ }^{66}$ да нису схватили шта потписују када су 357. год. подржали аријански кредо у Сирмијуму (Трећа сирмијска формула) - који св. Иларије назива Сирмијска бласфемија, јер наводно нису разумели разлику између речи оцоои́бюs

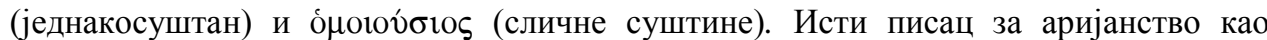
главне кривце драме која је настала у време Констанција II види и Валенса и Урсација, против којих је написао три књиге говора. ${ }^{67}$ Он и у свом трактату Contra Arianos тврди да је све Аријево “наслеђе" (лат. haereditas) пренето на Валенса, Урсација, Герминија и Гаја. Највероватније је израз употребљен у смислу духовно наслеђе, што нам потврђује и мало раније поменути Arii spiritus, а не телесно присуство учитеља. ${ }^{68}$

\footnotetext{
${ }^{61}$ Rowan Williams, нав. дело, 67.

${ }^{62}$ H.-G. Opitz, Urk. 4b, 10-11наводи осамнаест свештеничких потписа.

${ }^{63}$ Annette von Stockhausen, Hanns Christof Brennecke (Hrsg.), Von Arius zum Athanasianum. Studien zur Edition der »Athanasius Werke«, Göttingen 2010.

${ }^{64}$ Жак Зелер, Почецฺи хришћанства на Балкану (прев. Корнелија Никчевић), Подгорица 2005, 213-214.

${ }^{65}$ Ath. Ep. Aeg. Lib. 7.

${ }^{66}$ R. P. C. Hanson, нав. дело, 79.

${ }^{67}$ Lionel R. Wickham, Hilary of Poitiers. Conflicts of Conscience and Law in the Fourth-Century Church, Liverpool 2009; За даљи ток аријанских расправа у области данашњег Срема вид. Милена Милин, $O$ једној христолошкој расправи у Сирмију IV века, Старинар 49, 1998, 203-214; Александра СмирновБркић, Преписка иара Гратијана и св. Амбросија Миланског - прилог проучавағу аријанства у Срему, Споменица Историјскиг архива „Срем“ 9, 2010, 176-187; Свети Амвросије Милански у Сирмијуму прилог проучавағу аријанства у Срему, Други годишњи симпосион Српска теологија данас, 28-29. мај 2010, Зборник радова, Београд 2011, 147-157; упор. погл. Сирмијум и аријанство, М. Mirković, Sirmium. Istorija rimskog grada od I do kraja VI veka, Sremska Mitrovica 2006, 120-124.

${ }^{68}$ Hil. Pict. Con. Ar. 5: Hinc illae variae opiniones, hinc sub unius Christi fide praedicatio plurimorum, hinc nuper Arii spiritus ex angelo diaboli in lucis angelum transfiguratus: cujus haereditas omnis ad Valentem, Ursacium, Auxentium, Germinium, Gaium successit atque defluxit.
} 
На крају, када су исцрпљени сви писани извори, њихова недоследност и противречност понекад се да̄ надоместити археолошким материјалом. Ниједан од поменутих истраживача није узео у обзир материјална сведочанства о панонском хришћанству, јер, наиме, у својој спољној експресији аријанство се није разликовало од правоверног хришћанства, само у догматским питањима, те није могуће на основу археолошког материјала утврдити догматску афилијацију. Ипак, један податак из Мађарске који је публиковала реномирани археолог Едит Томас и објавила низ студија о ранохришћанским материјалним остацима са територије римских провинција Паноније, може бити релевантан за проблематику Аријевог изгона у Панонију. У питању је налаз из Кишдорога (Kisdorog) у мађарској Барањи, где је у позноантичком гробу пронађена цигла са урезаном представом човека и латинским натписом ARIO. Натпис представља вотивни дативски облик имена ARIUS. ${ }^{69}$ На јересијарха Арија даље упућује иконографија урезане људске фигуре, која представља ћелавог човека обученог у свештеничку одору са закривљеним епископским штапом у десној руци, а испод леве руке стоји сигла $P E$, тј. palma emerita, епиграфски симбол победе и у хришћанској и паганској употреби. ${ }^{70}$ На основу наведеног Томасова изводи следећи закључак: „Der verurteilte Arius muß in die Verbannung ziehen und kommt so mit seinen Anhängern in die Pannonien benachbarte Provinz Illyricum, von wo er eine starke Propagandatätigkeit ausübt“ “, ${ }^{71}$ и даље разлог касније појаве аријанских упоришта у Сирмијуму, Мурси, Сингидунуму, Петовију и Саварији, од којих ће прва три активно учествовати у христолошким расправама на црквеним саборима у другој пол. 4. века. Иако није јасно шта Томасова у наведеном одломку подразумева под провинцијом Илирик, јер таква није постојала у позној антици, ипак се овај извор не може олако одбацити, јер могуће сведочи о свести Аријевог наслеђа у Панонији, али свакако не представља потврду о његовом присуству у њој.

Тек на основу овог критичког прегледа укупног фонда извора различите провенијенције и достигнућа новије историографије, може се са извесном поузданошћу прецизиније лоцирати место Аријевог прогонства у простор римске Паноније, али без нових открића, никаква ближа убикација није могућа.

Извори и литература:

Извори:

Bidez, J. (Hrsg.), Philostorgius. Kirchengeschichte. Mit dem Leben des Lucian von Antiochien und den Fragmenten eines arianischen Historiographen, Leipzig 1913.

Brennecke, H. C. - Heil, U. - Stockhausen, A. V. - Wintjes, A., Athanasius Werke, Bd. 1-3, Berlin - New York 2007.

\footnotetext{
${ }^{69}$ Edit B. Thomas, Arius-Darstellung, eine römerzeitliche Ziegelritzzeichnung aus Kisdorog in Pannonien, Szekszárdi Béri Balogh Adám Muzeum Evkönyve 4-5, 1973-74/75, 77-116.

${ }^{70}$ Orazio Marucchi, Christian epigraphy, Cambridge 1912, 67-68.

${ }^{71}$ Edit B. Thomas, Das frühe Christentum in Pannonien im Lichte der archäologischen Funde, Severin zwischen Römerzeit und Völkerwanderung, Linz 1982, 286.
} 
Coleman-Norton, P. R., Roman State and the Christian Church. A Collection of Legal Documents to A.D. 535, vol. I-III, London 1966.

Dekkers, E. (ed.), Clavis patrum Latinorum, Steenburgen 1995.

Feder, A. (ed.), Collectanea Antiariana Parisina, CSEL, Paris 1916.

Geerard, M. (ed.), Clavis Patrum Graecorum, Turnout 1974.

Gunther, O. (ed.), Collectio Avellana, Leipzig 1895.

Hahn, A. (ed.), Bibliothek der Symbole und Glaubensregeln der alten Kirche, Leipzig 1897.

Migne, J.-P., Patrologiae cursus completus, s. Graeca, Paris 1844-1855.

Migne, J.-P., Patrologiae cursus completus, s. Latina, Paris 1844-1855.

Сократ Схоластик, Историја иркве (прев. владика Гаврило Поповић), Београд 1886.

Schaff, P. - Wice, H., Nicene and Post-Nicene Fathers of the Church, Edinburgh 1898.

Thesaurus Linguae Graecae - online access through the Foundation Hardt, GENEVA.

Wickham, L. R., Hilary of Poitiers. Conflicts of Conscience and Law in the Fourth-Century Church, Liverpool 2009.

Литература:

Ando,C. - Rüpke J. (eds.), Religion and Law in Classical and Christian Rome, Munchen 2006.

Barnes, T., The Exile and Recalls of Arius, Journal of Theological Studies, NS, 60, April 2009, 109129.

Barnes, T., Constantine and Eusebius, Cambridge 1981.

Barnes,Timothy D. The New Empire of Diocletian and Constantine, London 1982

Brennecke, H. C., Nicäa I. Ökumenische Synode von 325, Teologische Realenzyklopädie 24, 1994, 429-441.

Cancik, H. - Schneider, H. (eds.), Brill's New Pauly, Brill Online: Brill, 2012.

Coleman-Norton, P. R., Roman State and the Christian Church. A Collection of Legal Documents to A.D. 535, vol. I-III, London 1966.

Cross, F. L. E. - Livingstone, A., The Oxford Dictionary of the Christian Church, 3rd Ed., Oxford 1997.

De Ste. Croix, G. E. M., Why Were the Early Christians Persecuted? Past\&Present 26, Nov. 1963, 6-38.

De Ste. Croix, G. E. M., Why Were the Early Christians Persecuted? - A Rejoinder, Past\&Present 27, Apr. 1964, 28-33.

Gustafson, M., Condemnation to the Mines in the Later Roman Empire, The Harvard Theological Review, Vol. 87, No. 4 (Oct., 1994), 421-433.

Hanson, R. P. C., The Search for the Christian Doctrine of God. The Arian Controversy 318-381, Edinburgh 1988.

MacMullen, R., Judicial Savagery in the Roman Empire, Chiron 16, 1986, 43-62.

Marucchi, O., Christian epigraphy, Cambridge 1912.

Millar, F., Condemnation to Hard Labour in the Roman Empire, from the Julio-Claudians to Constantine, Papers of the British School at Rome 52, 1984, 124-147.

Милин, М., О једној христолошкој расправи у Сирмију IV века, Старинар 49, 1998, 203-214.

Mirković, M., Sirmium. Istorija rimskog grada od I do kraja VI veka, Sremska Mitrovica 2006.

Mocsy, A. - Frere, S., Pannonia and Upper Moesia. A History of the Middle Danube Provinces of the Roman Empire, London-Boston 1974.

Mommsen, T., Romisches Strafrecht, Leipzig 1899.

Opitz, H.-G., Die Zeitfolge des arianischen Streites von den Anfängen bis zum Jahr 328, ZNW 33, 1934, 131-159.

Opitz, H.-G., Athanasius’ Werke, Bd. 1-3, Berlin 1934. 
Папазоглу, Ф., О појмовима „Епир“ $и$ „Илирија“ у познорепубликанско доба, Годишњак Центра за балканолошка испитивања 13, 1976, 197-211.

Parvis, S., Marcellus of Ancyra and the lost years of Arian controversy, London 2006.

Pauly, A. - Wissova, G. - Kroll, W. - Witte, K. (Hrsg.), RE, Stuttgart1894-1980.

Rosser, J. H., Historical Dictionary of Byzantium, Boston 2001.

Schneemelcher, W., Zur Chronologie des arianischen Streites, Theologische Zeitschrift (Basel), 79, 1954, 393-400.

Schulthess, F., Die syrischen Kanones der Synoden von Nicaea bis Chalcedon, Abhandlungen der Königlichen Gesellschaft der Wissenschaften zu Göttingen, Philologisch-Historische Klasse N.F. 10, no. 2, Berlin 1908.

Schwarz, E., Von Nicaea bis zu Konstantins Tod. Eine grundsätzlich andere Chronologie, die allerdings auch von der Spätdatierung des Todes des Arius Mitte der dreißiger Jahre ausgeht, NGWG, 1911, 367-426.

Sheils, W. J. (ed.), Persecution and Toleration, Studies in Church History 21, Oxford, 1984.

Sidebotham, S. - Zitterkopf R. E. - Riley, J. A., Survey of the 'Abu Sha'ar-Nile Road, American Journal of Archaeology 95, 1991, 571-662.

Смирнов-Бркић, А., Преписка цฺара Гратијана и св. Амбросија Миланског - прилог проучавању аријанства у Срему, Споменица Историјскиг архива „Срем“ 9, 2010, 176-187;

Смирнов-Бркић, А., Свети Амвросије Милански у Сирмијуму - прилог проучавању аријанства y Срему, Други годишњи симпосион Српска теологија данас, 28-29. мај 2010, Зборник радова, Београд 2011, 147-157

Stockhausen, A. v. - Brennecke, H. C. (Hrsg.), Von Arius zum Athanasianum. Studien zur Edition der »Athanasius Werke«, Göttingen 2010.

Thomas, E. B., Arius-Darstellung, eine römerzeitliche Ziegelritzzeichnung aus Kisdorog in Pannonien, Szekszárdi Béri Balogh Adám Muzeum Evkönyve 4-5, 1973-74/75, 77-116.

Thomas, E. B., Das frühe Christentum in Pannonien im Lichte der archäologischen Funde, Severin zwischen Römerzeit und Völkerwanderung, Linz 1982.

Wickham, L. R., Hilary of Poitiers. Conflicts of Conscience and Law in the Fourth-Century Church, Liverpool 2009.

Wilkes, J., The Illyrians, Oxford 19962.

Williams, R., Arius. Heresy and Tradition, Cambridge 2002.

Зелер, Ж., Почеции хришћанства на Балкану (прев. Корнелија Никчевић), Подгорица 2005. 


\title{
THE EXILE OF ARIUS TO „ILLYRICUM“ ACCORDING TO HISTORICAL EVIDENCE
}

\begin{abstract}
Summary
The paper explores the location where the founder of Arian heresy, Alexandrian presbyter Arius, was exiled by the emperor Constantine I after the Nicene Council in 325. It has been generally accepted among researchers that the place of Arius's exile was "Illyricum", and the notion was too wide in the Late Roman Empire in order to give more precise location. However, many renowned authors narrowed this area down to one of the imperial residences in the Western Balkans - Sirmium, Serdica, Naissus being the most common choice. The author of this paper critically re-examines the written evidence of Arius's exile, including the archeological sources, so as to conclude that the written argumentation solely depends on a rather unreliable source (Philost. HE 1.9c). However, the paper offers a solution to the problem by comparing it to other indirect sources, such as the Roman penal code in the case of religious exile, the praxis of the exile among known cases, the relationship between Arius and later attested Arian bishops in Pannonia.
\end{abstract}

Keywords: Arius, Arianism, Illyricum, Sirmium, Valens, Ursacius, Pannonia. 